\title{
MORPHOLOGICAL AND SYNTACTICAL ERROR ANALYSIS ON STUDENTS' PROCEDURE TEXT WRITING
}

\author{
Laila Desnaranti \\ Program of Economic Education, Faculty of Social Science, University of Indraprasta PGRI \\ Jalan Nangka No. 58C Tanjung Barat, Jagakarsa, Jakarta Selatan 12530 \\ lailaranti@gmail.com
}

\begin{abstract}
The purpose of the research is to analyze morphological and syntactical errors in a procedure text that is made by students in a private vocational high school in Bogor. The research method that is used to analyze morphological and syntactical errors in the procedure texts made by the students is a content qualitative method that based only on a few procedure texts.After the researcher analyzes the procedure text, the researcher found that the students still make the morphological and syntactical errors in their writings. Most of students make syntactical errors of $60.4 \%$ and for the morphological errors releases in $39.6 \%$.
\end{abstract}

Key words: morphology, syntax, error analysis, writing, procedure text

\begin{abstract}
ABSTRAK
Tujuan dari penelitian ini adalah untuk menganalisis kesalahan morphologi dan sintaksis dalam teks prosedur yang disusun oleh para siswa sekolah menengah kejuruan swasta di Bogor. Metode penelitian yang digunakan untuk menganalisis kesalahan morfologi dan sintaksis dalam teks prosedur yang disusun oleh para siswa adalah metode kualitatif dengan analisis isi yang berdasarkan pada beberapa teks prosedur. Setelah penulis melakukan analisis teks prosedur, penulis menemukan bahwa para siswa masih melakukan kesalahan morfologi dan sintaksis dalam tulisan mereka. Sejumlah besar siswa melakukan kesalahan sintaksis yakni sebesar $60.4 \%$ dan untuk kesalahan morfologi sebesar $39.6 \%$.
\end{abstract}

Kata kunci: morfologi, sintaksis, analisis kesalahan, menulis, teks prosedur 


\section{INTRODUCTION}

A lot of countries in the world used English as their second language. The purpose of English lesson is to develop the competence of communication both in written and spoken. This competence will usually cover four main skills, they are listening, reading, speaking, and writing. These skills are related to each other and should be learnt thoroughly. In vocational high school, English is taught as a main subject. The students must be able to master the four skills, they are, listening, reading, speaking, and writing. In addition, they should also master English components such as grammar, vocabulary, and pronunciation.

As the researcher has mentioned before, when learning English, there are related four skills that have to be mastered. In other words, they cannot stand alone. Listening and reading are classified as receptive skill, whereas writing and speaking are classified as productive skill. All four comprehensions need to be mastered well and balanced. Although the four skills are learnt at schools, the researcher would like to focus on writing comprehension.

Writing needs much effort and practice in combining, developing and analyzing an idea as affirmed by Hadley (2001:21), "Writing also involves composing, which implies the ability either to tell or retell pieces of information in the form of narrative or description, or to transform information to new texts, as in expository or argumentative writing". There are a lot of students who cannot use their learning experience in the real life for communicating especially in writing. There is no doubt when composing words into a paragraph which can cause troubles to the students.

The ability to write well is not as a naturally acquired skill. It is usually learnt or culturally transmitted as a set of practices in formal instructional settings or other environments. Writing must be practiced and learnt through experience. Having the ability to convey messages in writing effectively is not an easy task to master. In fact, it is an intricate and complex task. In the process of mastering English language, many mistakes are made by these students. In addition, it is crucial for students to learn how to write compositions accurately and fluently, especially in their writing tasks and even of their examinations. Writing, in other words, plays a very important role for students for them to be successful in their studies. As L2 learners, interference of their mother tongue is one of the factors affecting their English language proficiency, and it is unavoidable.

Aitchison (2010:20) stated that "Morpheme is the smallest syntactic unit". Morpheme varies in size. Neither syllables nor length are any guide to their identification. The essential criterion is that a morpheme cannot be cut up into smaller syntactic segments. Words are not the most elemental sound-meaning units; some words are structurally complex. The most elemental grammatical units in a language are morphemes.

The students have to know the basic grammar of English, includes morphology and syntax. Syntax is the rules of language that show how words of that language are arranged to make sentences of that language. If words are language's bricks then syntax is the wall. Simply put, syntax is the rules for how to make a sentence. It governs the relationships between words. Syntax is basically the structure of sentences. Sentences have to follow certain structural rules in order to make sense. It is a mistake to believe that some English speakers follow rules in their speech and 
others do not.

In the teaching and learning process of writing, the teacher has an important role. Writing a procedure text is one of the writing competencies that the students have to produce or performed. Procedure text is a common factual genre that provides instructions on how to do something. Further, Anderson and Kathy (1998:2) explain that "Procedure is a piece of text that tells the reader or listener how to do something". The purpose of procedure text is to provide sequenced information or directions so that people can successfully perform activities in safe, efficient, and appropriate ways.

Procedure text isalready familiar with people's daily life, for example in giving instructions to make something, in games rules, in recipes, manual steps, directions of destination (Derewianka and Frances,2004). The context of procedure text consists of three parts, namely: 1) title or goal is the goal of the text that gives the writer'spurpose ofexplaining what to do in the text. The goal of the text is the title of the text itself; 2) list of material. This part explains what things are required. Itmaybe tools, spices or ingredients (if the goal is to make some food or drinks); and 3) steps/method/procedures. These are the pointsonthe processof doing something in a sequenceorder.

There are also some language features that are used to make a text. In procedure text, the language features are: 1) the use simple present tense, 2) the use of imperatives (e.g.: cut, don't mix), 3) the use of action verbs (e.g.: turn, put, mix), 4) the use of connectives (e.g.: first, then, finally, etc.), and 5) the use of adverbial phrases (e.g.: for five minutes, 2 centimeters from the top).

Error in English can happen any time, in listening, speaking, reading and writing, especially in making a composition. For example, choosing the right word, arranging sentences with the right pattern, the right punctuation and other element. There are so many rules in English grammar that are different or even do not exist in Indonesian language that make students have difficulties in learning English.

Errors that are found in the active or expressive of language, i.e.,in speaking and writing skills are called expressive errors. On the other hand, errors that are traced in the passive of language, i.e., reading comprehension and listening skills are called receptive errors. The examples of receptive errors can be traced among the beginners who face difficulty in interpreting the linguistic features of an utterance. The process of learning English as a foreign language is actually a process of making errors, correcting errors and promoting the acquisition level.

Some errors seem to be as the natural accompaniment of learning a new skill or the inevitable slips of the pen. Others are seem intractable, persistent, and resistant to instruction like an insect that has developed resistance to insecticide. Given the prestige society attaches to correctness in writing, teachers often feel duty-bound to note, to mark, and to correct every error in a student's paper then to follow the papers with skills drills.

However, students' errors are considered as a meaningful input especially for English teachers. These errors are as an important elements that their function as a feed back in learning and teaching process. Related to the errors made by students, especially in writing, a lot of researchers have done some research by analyzing the errors made by student that are called 'Error Analysis'. Error Analysis is a type of linguistic analysis that focused on the error learners make. It consists of 
comparison between the errors made in the target language (TL) and TL itself.

The researchers are interested in analyzing the error because they believed that behind all those errors, there is information that can be used to fix it. In this research, the researcher is interested in analyzing the learner's error and wants to know the factors that make the students commit many errors. As stated by Richards (2005) and Dulay and Burt (1982), researchers are interested in errors because they are believed to contain valuable information on the strategies that people use to acquire language. The reality is most of the students in Indonesia especially Vocational High School students are not able to master English like they are expected. The students are still not able to use English for expressing their ideas, intention, and feelings through writing.

\section{METHOD}

The target population in this research were 150 students in class XI at Private Vocational High School in Bogor. The researcher only chooses 35 students by using purposive sampling techniques. In this study, the researcher uses random purposive sampling (with small sample) to determine the number of the students that were studied.

The technique which is used in collecting data is a test technique as a secondary resource. The material was not given directly to the students. The data was collected from the students' writing of procedure text. First, the researcher gives an explanation about the procedure text and how to make a procedure text to the students. Then the researcher asksthe students to make their own procedure text. After that, the researcher collects the students' writings and analyzes them to find out the errors. Finally, the researcher takes some conclusion about the errors found in the students' writing.

The method that is used in this study is a qualitative content analysis. In this research, the researcher describes the types of error based on the surface strategy taxonomy. This taxonomy classifies errors according to:

1. Omission: Omission errors are characterized by the absence of an item that must appear in a wellformed utterance.

2. Addition: Three types of addition errors are double marking, regularization and simple addition.

3. Double marking: Double markingerrors are described as the failure to delete certain items which are required in some linguistic constructions, but not in others. For example: He didn't went instead of He didn't go.

4. Regularization is defined as applying a rule to the class of exceptions. For example: sheeps instead of sheep.

5. Simple Addition errors are the "grab bug" subcategory of additions. If an addition error is not a double marking nor a regularization, it is called a simple addition. For example, it is consist of instead of it consists of.

6. Misformation errors are characterized by the use of the wrong form of a morpheme or structure. Three types of misformation errors are regularization errors, archi-forms and alternating forms.

7. Regularization errors that fall under the misformation category are those in which a regular marker is used in place of an irregular one as runned for ran.

8. Archi-forms are one member of a class of forms selected by the learner to represent others in the class as that dog, that dogs.

9. Alternating forms: As the learners' vocabulary and grammar grow, the 
use of archi-forms often gives a way to the free alternation of various members of a class with each other as those dog, this cats.

10. Misordering errors are characterized by the incorrect placement of a morpheme or group of morphemes in an utterance. For example, All the time in $\mathrm{He}$ is all the time late is misordered.

The researcher uses the surface strategy taxonomy as either the only one or combined with some other taxonomy. This taxonomy is also useful for organizing the collected data. To obtain the desired depth of information, qualitative researcher must almost always deal with small samples. Because the samples need to be small, and because of many potential participants, sampling in qualitative research is almost always purposive. The method used in taking the sample is simple random sampling, which means the samples are taken randomly from the population.

\section{RESULTS AND DISCUSSION}

The data is students' procedures writing from 150 students. The researcher chooses 35 writings as samples and all of them are from class XI. In this research, researcher used random purposive sampling (with small sample).

After the researcher analyzed 35 students' writings, the researcher found the types of error that the students did and also found the most dominant error type. The researcher analyzed the morphological and syntactical errors from the students' procedure text writings. The errors will be analyzed based on the surface strategy taxonomy which consists of some aspects, namely: omission, addition (double marking, regularization, and simple addition errors), misformation (regularization errors, archi-forms and alternating form) and misordering.

Sentences that are taken from the students' writing will be called students' errors and the right one will be called construction. From the analysis, the researcher found that in one sentence, there are more than one errors. That is why the researcher counts the errors based on student's errors not from the number of students. Every error will be classified according to its type. Here are some of the analysis:

Morphological Errors

\begin{tabular}{|l|l|}
\hline \multicolumn{1}{|c|}{$\begin{array}{c}\text { Students' } \\
\text { Errors }\end{array}$} & \multicolumn{1}{c|}{ Construction } \\
\hline metball & meatball \\
\hline $\begin{array}{l}\text { one sacet pop } \\
\text { ice }\end{array}$ & one sachet pop ice \\
\hline mesis & meisis \\
\hline chees & cheese \\
\hline $\begin{array}{l}\text { First, pour ice } \\
\text { to peel one } \\
\text { sacet. }\end{array}$ & $\begin{array}{l}\text { First, pour ice and } \\
\text { open one sachet }\end{array}$ \\
\hline $\begin{array}{l}\text { salt, peper, and } \\
\text { other spices }\end{array}$ & $\begin{array}{l}\text { salt, pepper, and } \\
\text { other spices }\end{array}$ \\
\hline $\begin{array}{l}\text { Donnuts is a my } \\
\text { favorite food. }\end{array}$ & $\begin{array}{l}\text { Doughnut is my } \\
\text { favorite food. }\end{array}$ \\
\hline $\begin{array}{l}\text { How to make a } \\
\text { donnuts }\end{array}$ & $\begin{array}{l}\text { How to make a } \\
\text { doughnut }\end{array}$ \\
\hline $\begin{array}{l}\text { The jus is ready } \\
\text { to be served }\end{array}$ & $\begin{array}{l}\text { The juice is ready } \\
\text { to be served }\end{array}$ \\
\hline $\begin{array}{l}\text { Everybody like } \\
\text { iced strawberry } \\
\text { coffe }\end{array}$ & $\begin{array}{l}\text { Everybody likes } \\
\text { iced strawberry } \\
\text { coffee }\end{array}$ \\
\hline 2 glass of water & 2 glasses of water \\
\hline trey & tray \\
\hline $\begin{array}{l}\text { Coffee : } 2 \text { tea } \\
\text { spoon }\end{array}$ & $\begin{array}{l}\text { Coffee } \text { : } 2 \\
\text { spoons }\end{array}$ \\
\hline 1 saset gelatin & sachet gelatin \\
\hline
\end{tabular}

The researcher found that there are 43 errors for omission from morphological errors in students' writings. It means that $72.8 \%$ of the 
students do this error. Moreover, the researcher found that there are 7 errors for additionfrom morphological errors in students' writings. That means $11.8 \%$ of the writings have these errors. For double marking error from addition error, there is only 1 writing has the error. The researcher found only one of this error on the students' procedures text writing, so it is $14.3 \%$ from the addition errors. For regularization error from addition error, there is no writing has the error. The researcher does not find any errors in this area on the students' procedures text writing. Simple addition error from addition errors releases 6 errors in the writing. Furthermore, researcher found 6 errors on the students' procedures text writing, of $85.7 \%$ from the addition errors. The researcher found there 5 errors for misformation from morphological errors in students' writings. That means $8,5 \%$ of the writings have this errors. Misformation is divided into 3 kinds. There are regularization errors, archi-forms and alternating form. For regularization error from misformation errors, there is only a writing has the error. Researcher found only one error on the students' procedures text writings, so it is $20 \%$ from the misformation errors. For archiforms error from misformation errors, there is one writing has the error.

Accordingly, the researcher found only one error on the students' procedures text writing, results about $20 \%$ from the misformation errors. Also, the researcher found 3 errors for alternating form from misformation errors in students' writing. It means that there is $60 \%$ of the writings have this error. The researcher found 4 errors for misordering from morphological errors in students' writings. That means about $6.8 \%$ of the writings have this errors.

Here are some examples for Syntactical Errors that the researcher found:

\section{Syntactical Errors}

\begin{tabular}{|c|c|}
\hline Students'Errors & \\
\hline $\begin{array}{l}\text { Because, fried rice } \\
\text { is delicious food }\end{array}$ & \\
\hline $\begin{array}{lll}\text { Salad } & \text { fruit } & \text { good } \\
\text { food } & \text { for } & \text { your } \\
\text { health } & & \\
\end{array}$ & $\begin{array}{l}\text { Salad fruit is good } \\
\text { food for your } \\
\text { health }\end{array}$ \\
\hline $\begin{array}{l}\text { not difficult to } \\
\text { hake }\end{array}$ & \\
\hline $\begin{array}{l}\text { Fried rice my } \\
\text { favorite } \\
\text { breakfast }\end{array}$ & $\begin{array}{l}\text { Fried rice is my } \\
\text { favorite menu for } \\
\text { breakfast }\end{array}$ \\
\hline $\begin{array}{l}\text { Easy to make fried } \\
\text { rice }\end{array}$ & $\begin{array}{l}\text { y to make } \\
\text { e }\end{array}$ \\
\hline $\begin{array}{l}\text { Spaghetti } \\
\text { Italian food }\end{array}$ & $\begin{array}{l}\text { tti is an } \\
\text { food }\end{array}$ \\
\hline $\begin{array}{l}\text { Finally, juice } \\
\text { ready to served }\end{array}$ & $\begin{array}{l}\text { juice is } \\
\text { be served }\end{array}$ \\
\hline $\begin{array}{l}\text { Fried rice very } \\
\text { nice when we eat } \\
\text { early in the } \\
\text { morning }\end{array}$ & $\begin{array}{l}\text { Fried rice is very } \\
\text { nice when we eat } \\
\text { early in the } \\
\text { morning }\end{array}$ \\
\hline delicious & us it is \\
\hline $\begin{array}{l}\text { I like make an } \\
\text { avocado juice }\end{array}$ & $\begin{array}{l}\text { make an } \\
\text { juice }\end{array}$ \\
\hline 200 gram of flour & 200 grams of flour \\
\hline $\begin{array}{l}100 \text { grams of } \\
\text { margarin }\end{array}$ & $\begin{array}{l}100 \text { grams of } \\
\text { margarine }\end{array}$ \\
\hline $\begin{array}{lr}\text { Finally } & \text { choco } \\
\text { banana } & \text { ready to } \\
\text { eat }\end{array}$ & $\begin{array}{l}\text { Finally Choco } \\
\text { banana is ready to } \\
\text { eat }\end{array}$ \\
\hline $\begin{array}{l}\text { Burger is } \\
\text { from USA }\end{array}$ & $\begin{array}{l}\text { is a food } \\
\text { A }\end{array}$ \\
\hline $\begin{array}{l}\text { Although this fast } \\
\text { food but this food } \\
\text { delicious }\end{array}$ & $\begin{array}{l}\text { gh this is } \\
\text { od but this } \\
\text { delicious }\end{array}$ \\
\hline & and \\
\hline
\end{tabular}

The researcher found that there are 26 errors for omission from syntactical errors in students' writings. Hence, of 
which about $28.8 \%$ of the writings have this error. Also, the researcher found there are 36 errors for addition from syntactical errors in students' writings. It means that $40 \%$ of the writings have these errors.

The error of addition is divided into three kinds, they are double marking, regularization, and simple addition errors. For double marking error from addition errors, the researcher found 23 errors on the students' procedures text writings. With this result, the researcher found that it is about $63.8 \%$ from the addition errors. For regularization error from addition errors, there is no writing has the error. The researcher didn't find any errors in this area on the students' procedures text writings. For simple addition error from addition errors, there are 13 errors in the writings. The researcher found 13 errors on the students' procedures text writings, so it is about $36.1 \%$ from the addition errors.

Accordingly, the researcher found 6 errors for misformation from syntactical errors in students' writings. That means of which around $10.1 \%$ of the writings have these errors. Misformation is divided into three kinds, they are regularization errors, archiforms and alternating form. For regularization error from misformation error, there is no writing have this error. The researcher does not find any errors in this area on the students' procedures text writings. For archi-forms error from misformation errors, there are 5 writings have the error. The researcher found 5 errors on the students' procedures text writings, so it is $83.3 \%$ from the misformation errors. For regularization error from misformation errors, there is only one writing has the error. The researcher found only one error on the students' procedures text writings, so it is $16.6 \%$ from the misformation errors.
The researcher found 22 errors for misordering from syntactical errors in students' writings. It means that is about $24.4 \%$ of the writings have these kind of errors.

All of the errors are shown in the table below:

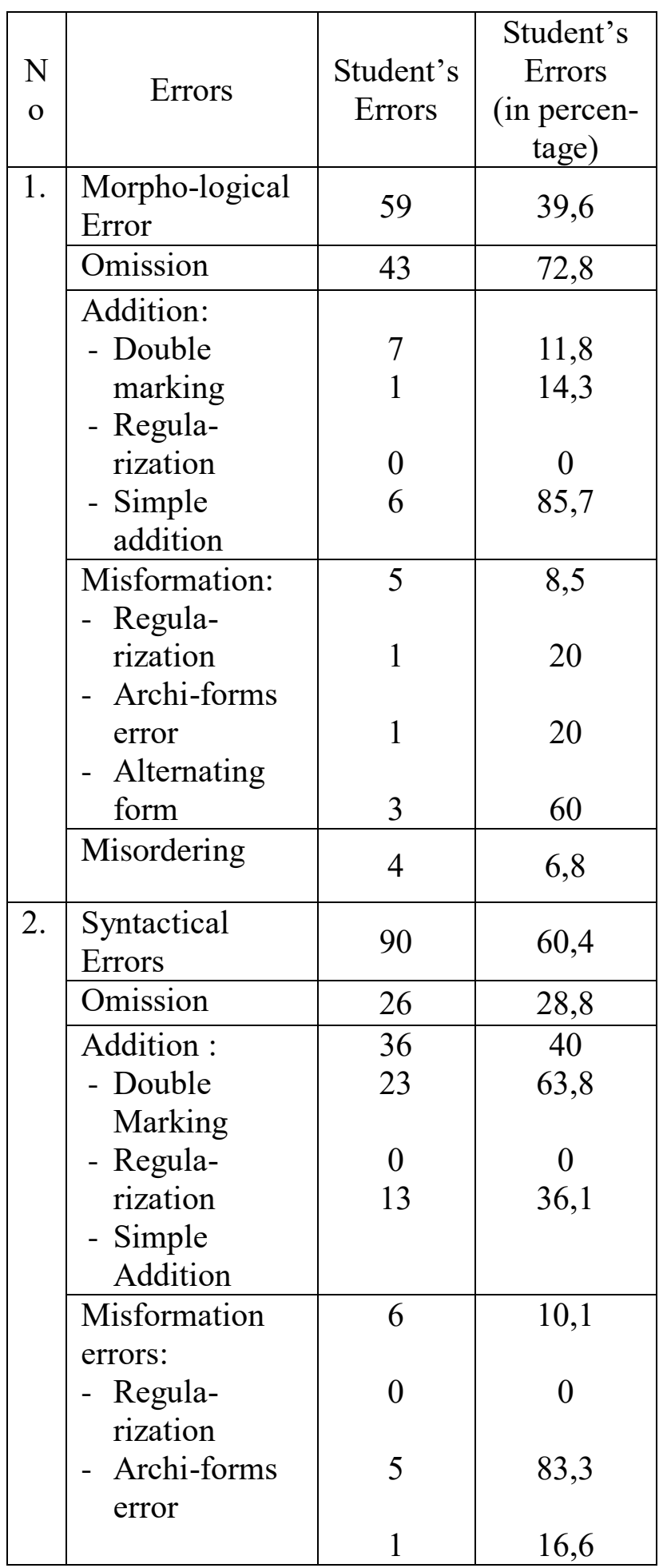




\begin{tabular}{|l|l|l|l|}
\hline \multirow{2}{*}{$\begin{array}{l}\text { - Alternating } \\
\text { form }\end{array}$} & & \\
\cline { 2 - 4 } & Misordering & 22 & 24,4 \\
\hline
\end{tabular}

The results of the research are also able to be seen in the chart below:

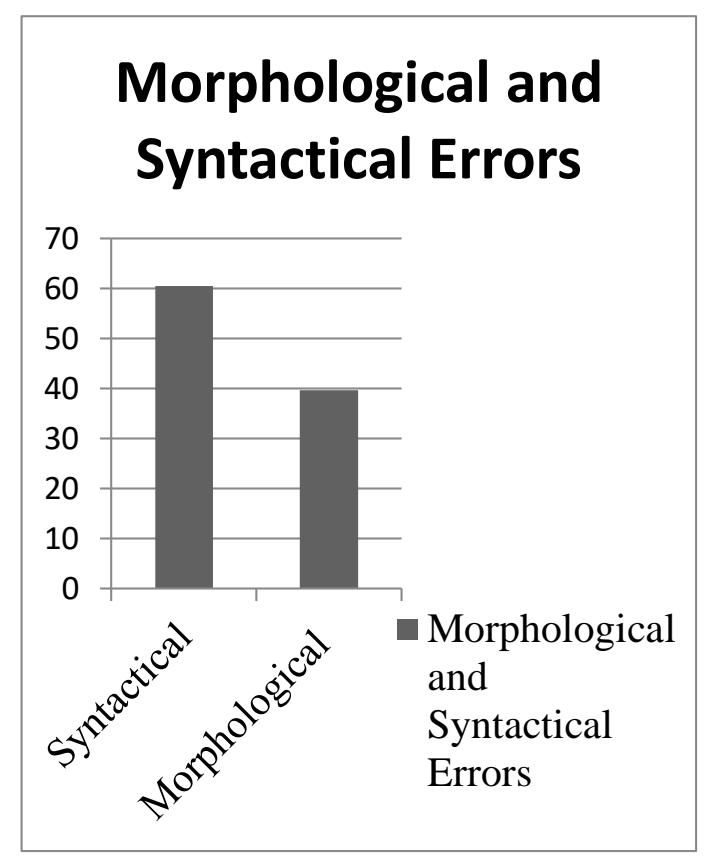

Figure 1. Morphological and Syntactical Errors

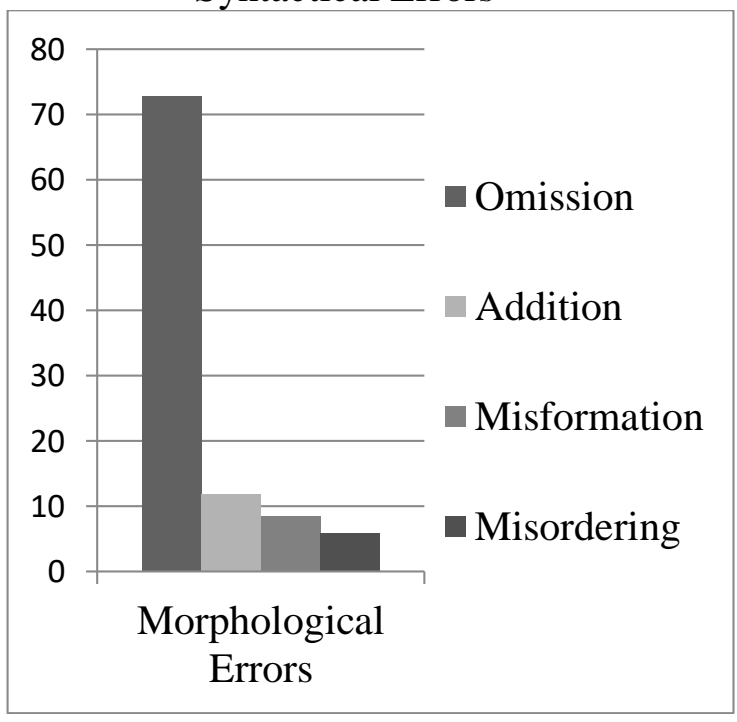

Figure 2.Morphological Errors

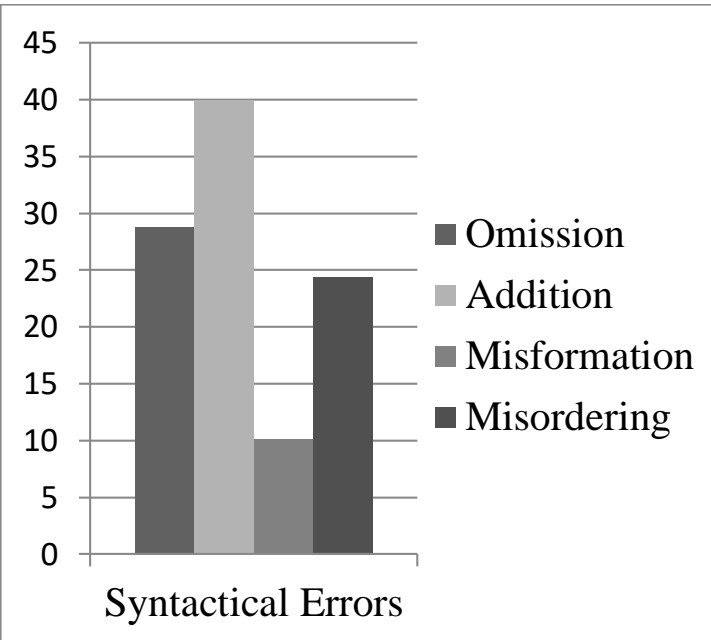

Figure 3. Syntactical Errors

\section{CONCLUSION}

After the researcher analyzed the error, the researcher found that from 35 writings, there are 149 errors identified. They are 59 (39.6\%) morphological errors and 90 (60.4\%) syntactical errors. For morphological error, there are 43 $(72.8 \%)$ errors of omission, $7(11.8 \%)$ errors of addition, $5(8.5 \%)$ errors of misformation, and $4(6.8 \%)$ errors of misordering. For syntactical errors there are $26(28.8 \%)$ errors of omission, 36 $(40 \%)$ errors of addition, $6(10.1 \%)$ errors of misformation, and 22 (24.4\%) errors of misordering.

Most of the students have not mastered the target language very well. That is why they make a lot of errors in morphological as well as in syntactical. Most of the students are also influenced by their mother tongue. Therefore, they transferred directly to their mother tongue even it is a grammatically error. The errors that are made by the students may be caused from the teacher's teaching method. The studentsare not used to make or to write an English text especially procedure text by the English teachers, so they get some difficulties when they are asked to make one. 


\section{REFERENCES}

Aitchison, J. (2010). Aitchison's Linguistics: Teach Yourself. United Kingdom: Hachette.

Anderson, M., \&Kathy, A. (2003). Text Type in English 1. South Yarra: Macmillan Education PTY LTD.

Derewianka, B.,\& Frances, C. (2010). School Discourse: Learning to Write Across the Years of Schooling. New York: Bloomsbury.
Dulay, H. \& Burt, M. (1982). Language Two. Oxford: Oxford University Press.

Hadley, O. (2001). Teaching Language in Context. Boston: Heinle \&Heinle.

Richards, B, J. (2005). Language Development and Individual Differences. Cambridge: Cambridge University Press. 